\title{
Determination of the optimum plot size for tomato seedlings ${ }^{1}$
}

\author{
Jeniffer Ribeiro de Oliveira ${ }^{2 *} \mathbb{D}$, Weslley do Rosário Santana ${ }^{2}$, Mayara Nascimento Santos $^{3}$, Edilson Romais Schmildt ${ }^{2}$ \\ $10.1590 / 0034-737 X 202168020006$
}

\begin{abstract}
The objectives of this work were to determine the optimum plot size for tomato seedlings by Hatheway's method, using the Mestiço and Ozone cultivars, and verify the possibility to obtain the optimum plot size only by nondestructive characteristics. Non-destructives (aerial part height, stem diameter, number of leaves and leaf area) and destructives (aerial part dry matter, root dry matter, total dry matter and Dickson quality index) characteristics were evaluated. For each characteristic evaluated, experimental plans were simulated in a randomized block design with the combination of $\mathrm{I}$ treatments $(\mathrm{I}=3,4,5, \ldots, 10,15,20$ and 25) and $\mathrm{R}$ repetitions $(\mathrm{R}=3,4,5,6$ and 7$)$. The optimum plot size ranged according to the characteristic evaluated. Considering the number of treatments, repetitions and the same experimental accuracy, the stem diameter showed the highest size plot. Thus, the stem diameter can be used as a basis characteristic for the non-destructives characteristics, without the need to destroy the seedling.
\end{abstract}

Keywords: Solanum lycopersicum; experimental precision; experimental planning; experimental design.

\section{INTRODUCTION}

Regarding experiments with tomato seedling production, there is no standardization in the plot size. There are works with one plant per plot (Soares et al., 2013), 5 plants per plot (Sirtoli et al., 2011), 16 plants per plot (Bernardes et al., 2011) and 24 plants per plot (Nadai et al., 2015).

It points out that the demand for research with tomato seedlings is enormous due to the constant evolution of the production process, with the need to evaluate new substrates, new active pesticide principles, fertilizing seedlings, new cultivars, among others. Thus, the determination of the optimum plot size based on scientific criteria is extremely important to give greater credibility to the experimental results (Storck et al., 2011).

The most often method used to determine the optimum plot size is the modified maximum curvature, according to Meier \& Lessman (1971). Another method that has been widely used in recent years is the method of maximum curvature of the coefficient of variation (Paranaíba et al., 2009), which has the great advantage of reducing calculations to determine the optimum plot size. Recently, bootstrap simulation has been incorporated into some methods, among which we can mention: incorporation to Paranaíba et al. (2009) method made by Santos et al. (2012) and Storck et al. (2014); incorporation of the linear response plateau method by Brito et al. (2014); and, incorporation to Meier \& Lessman's (1971) method made by Leonardo et al. (2014). All of these methods, with or without bootstrap simulation, allow us only to determine the optimum plot size, without giving resources to determine the number of plots involved, which can be obtained, however, by Hatheway's (1961) method. Through this method, the wishes of the researcher who wants to know the optimum plot size for his research reality can be satisfied, which also includes the number of treatments and repetitions, the experimental design used and the precision of the experiment. The data necessary to use

\footnotetext{
Submitted on May $12^{\text {th }}, 2020$ and accepted on October $18^{\text {th }}, 2020$

${ }^{1}$ This work is part of the first author's scientific research.

${ }^{2}$ Universidade Federal do Espírito Santo, Departamento de Ciências Agrárias e Biológicas, São Mateus, Espírito Santo, Brazil. jeniffer.jr1994@gmail.com; weslley.rosario@hotmail.com; e.romais.s@gmail.com

${ }^{3}$ Universidade de Vila Velha, Vila Velha, Espírito Santo, Brazil. mayaratirsa@gmail.com

*Corresponding author: jeniffer.jr1994@gmail.com
}

Rev. Ceres, Viçosa, v. 68, n.2, p. 126-134, mar/apr, 2021 
Hatheway's method are obtained from blank test and the optimum plot size can be determined for any experimental designs. Celanti et al. (2016b) used Hatheway's method for completely randomized design, randomized block design and Latin square.

Studies that determine the optimum plot size with tomato seedlings were not found in literature. Thus, the objectives of this work were to determine the optimum plot size and verify the possibility to obtain the optimum plot size only by non-destructive characteristics, for tomato seedlings.

\section{MATERIAL AND METHODS}

This work used seedlings of Mestiço and Ozone cultivars. The seedlings were produced by the company Top Mudas ${ }^{\circledR}$, located in the municipality of Venda Nova do Imigrante, State of Espírito Santo.

The seedlings were produced in polyethylene trays with 200 cells, whose capacity of each cell was of $18 \mathrm{~cm}^{3}$, containing Carolina Soil@ substrate. The substrate was composed by Sphagnum peat, expanded vermiculite, dolomitic limestone, gypsum and NPK fertilizer. Three seeds per cell were used to obtain the seedlings and, after reaching about $3 \mathrm{~cm}$, thinning was carried out, selecting the seedling in better condition, being kept in a nursery with anti-phallic mesh.

The 200 seedlings of Mestiço cultivar were evaluated on September 25, 2017, 31 days after sowing, and the seedlings of Ozone cultivar were evaluated on March 12, 2018, 24 days after sowing. The seedlings of each cultivar were evaluated as blank test. For each evaluated characteristic, experimental plans were simulated in a randomized block design, for the scenarios formed by the combinations of I treatments ( $\mathrm{I}=3,4,5, \ldots, 10,15,20$ and 25), $R$ repetitions ( $r=3,4,5,6$ and 7) and D differences between treatment averages to be detected as significant at $5 \%$ probability, expressed as a percentage of the overall uniformity test mean $(\mathrm{D}=10,20,30$ and $40 \%)$.

The following evaluations were conducted at the end of each experiment at each seedling: aerial part height $(\mathrm{APH})$, determined with a ruler graduated in $\mathrm{cm}$; stem diameter (SD), measured with a digital caliper, in $\mathrm{mm}$; number of leaves (NL), by counting the final developed leaves; leaf area (LA), measured with the aid of the ImageJ® Software (Schindelin et al., 2015) from the scanned leaves in 75 tif in an HP Deskjet F4480 multifunctional; aerial part dry matter (APDM), in g; root dry matter (RDM), in g; total dry matter (TDM), by the sum of APDM and RDM, in g; Dickson quality index (DQI) according to Dickson et al. (1960), through the equation: $\mathrm{DQI}=\mathrm{TDM} /\{(\mathrm{APH} / \mathrm{SD})+(\mathrm{APDM} / \mathrm{RDM})\}$. For determining the APDM and RDM per plant, the seedlings were dried, separately, in a forced circulation oven
(FANEM Mod.320 SE) at $70{ }^{\circ} \mathrm{C}$ until constant mass, and then, their masses obtained on a precision scale (BEL ENGINEERING MARKM214A).

After, the data collection were analyzed, generating descriptive statistics and normality test using the ShapiroWilk test. These analyzes were carried out with the purpose of characterizing two blank tests, for Mestiço and Ozone cultivars, and verifying their suitability for the study of optimum plot size.

The possibility of reducing the number of characteristics to be evaluated to determine the plot size through the study of correlations was evaluated. Thus, Pearson's linear correlation was determined, applying the same in the relationships between the eight characteristics, two by two, for the two varieties, totaling 28 correlation values for each variety studied. Pearson's correlation analysis had the statistical significance verified by $5 \%$ and $1 \% \mathrm{t}$ test, and the magnitudes classified according to Shimakura \& Júnior (2012), where, regardless of the sign, a correlation is considered very weak between 0.00 to 0.19 ; weak between 0.20 to 0.39 ; moderate between 0.40 to 0.69 ; strong between 0.70 to 0.89 and very strong between 0.90 to 1.00 .

Based on Pearson correlation values obtained, the correlation matrices were structured for analysis by the canonical correlation, with two groups being established: the seedlings destructive characteristics (APDM, RDM, TDM and DQI) and non-destructive characteristics (APH, $\mathrm{SD}, \mathrm{NL}$ and LA). The analysis of the correlation between the two groups was carried out only after verifying the presence of multicollinearity. The statistical significance of the canonical correlation was performed by chi-square test.

With the results, the characteristic that contributed most to its existence was eliminated from the analysis of the canonical correlation. By the result of the analysis of the canonical correlation, it was tried to detect if any of the non-destructive characteristics can be used in substitution to the destructive characteristics in determining the optimal plot size.

To determine the optimal plot size $\left(\mathrm{X}_{0}\right)$, the method according to Hatheway (1961) was used, using R software (R Development Core Team, 2018), using bootstrap simulation. The equation is given by $x_{0}=\sqrt[b]{2\left(t_{1}+t_{2}\right)^{2} \frac{C V^{2}}{R D^{2}}}$, whose: $\mathrm{b}=$ Smith's heterogeneity index (1938); CV = estimative of the coefficient of variation between the portions of a UEB of size, in percentage; $\mathrm{R}=$ number of repetitions considered; $\mathrm{D}=$ difference between treatment averages to be detected as significant at $5 \%$ probability, expressed as a percentage of the overall average of the uniformity test; $t_{1}=$ tabulated value of $t$ for tests of significance (bilateral test at 5\%), with df degrees of 
freedom; $\mathrm{t}_{2}=$ tabulated value of $\mathrm{t}$, bilateral, corresponding to an error of 2 (1-p), with df degrees of freedom, with $\mathrm{p}=$ 0.80 the probability of obtaining significant results.
The tabulated values of the $t$ distribution were obtained with df degrees of freedom of the residue, depending on the I treatments and $\mathrm{R}$ repetitions, with $\mathrm{df}=$

Table 1: Minimum, maximum, mean, standard deviation (SD), coefficient of variation (CV) and p-value of Shapiro-Wilk normality test (SW) for eight characteristics evaluated in tomato seedlings (Solanum Iycopersicum), Mestiço and Ozone cultivars

\begin{tabular}{|c|c|c|c|c|c|c|}
\hline Characteristics $^{(1)}$ & Minimum & Maximum & Mean $^{(2)}$ & SD & CV (\%) & $\mathbf{S W}^{(3)}$ \\
\hline APH, 'Mestiço' & 3.85 & 9.00 & $7.26 \mathrm{a}$ & 0.80 & 11.05 & $<0.01$ \\
\hline APH, 'Ozone' & 3.70 & 8.00 & $6.63 b$ & 0.55 & 8.37 & $<0.01$ \\
\hline SD, 'Mestiço' & 0.77 & 3.92 & $2.37 \mathrm{a}$ & 0.58 & 24.26 & 0.01 \\
\hline SD, 'Ozone' & 1.43 & 3.21 & $2.25 \mathrm{a}$ & 0.27 & 12.19 & 0.33 \\
\hline NL, 'Mestiço' & 2.00 & 4.00 & $2.99 \mathrm{a}$ & 0.34 & 11.44 & $<0.01$ \\
\hline NL, 'Ozone' & 2.00 & 3.00 & $2.15 b$ & 0.36 & 16.65 & $<0.01$ \\
\hline LA, 'Mestiço' & 16.96 & 49.34 & $36.52 \mathrm{a}$ & 5.12 & 14.01 & $<0.01$ \\
\hline LA, 'Ozone' & 3.98 & 28.71 & $17.41 \mathrm{~b}$ & 3.75 & 21.56 & 0.68 \\
\hline APDM, 'Mestiço' & 0.10 & 0.22 & $0.15 \mathrm{a}$ & 0.03 & 19.6 & $<0.01$ \\
\hline APDM, 'Ozone' & 0.02 & 0.13 & $0.08 \mathrm{~b}$ & 0.02 & 23.9 & 0.61 \\
\hline RDM, 'Mestiço' & 0.03 & 0.10 & $0.06 \mathrm{a}$ & 0.02 & 26.82 & 0.04 \\
\hline RDM, 'Ozone' & 0.01 & 0.05 & $0.03 b$ & 0.01 & 29.92 & 0.02 \\
\hline TDM, 'Mestiço' & 0.15 & 0.31 & $0.21 \mathrm{a}$ & 0.04 & 19.53 & $<0.01$ \\
\hline TDM, 'Ozone' & 0.03 & 0.17 & $0.10 \mathrm{~b}$ & 0.02 & 22.09 & 0.54 \\
\hline DQI, 'Mestiço' & 0.02 & 0.06 & $0.04 \mathrm{a}$ & 0.01 & 27.19 & 0.11 \\
\hline DQI, 'Ozone' & 0.01 & 0.03 & $0.02 b$ & 0.005 & 27.06 & 0.29 \\
\hline
\end{tabular}

(1) $\mathrm{APH}=$ aerial part height $(\mathrm{cm}) ; \mathrm{SD}=$ stem diameter $(\mathrm{mm}) ; \mathrm{NL}=$ number of leaves; $\mathrm{LA}=$ leaf area per seedling $\left(\mathrm{cm}^{2}\right)$; $\mathrm{APDM}=$ aerial part dry matter $(\mathrm{g}) ; \mathrm{RDM}=$ root dry matter $(\mathrm{g}) ; \mathrm{TDM}=$ total dry matter $(\mathrm{g}) ; \mathrm{DQI}=$ Dickson quality index

(2) Means for the same trait, evaluated between two cultivars, followed by the same letter, do not differ statistically from each other by $\mathrm{t}$ test at $5 \%$ probability.

(3) $\mathrm{p}$-value above 0.05 indicates normality of the data at $5 \%$ probability.

Table 2: Pearson (r) linear correlation coefficients matrix between eight characteristics of tomato seedlings (Solanum Iycopersicum), Mestiço and Ozone cultivars

\begin{tabular}{|c|c|c|c|c|c|c|c|c|}
\hline \multirow{2}{*}{ Characteristic $^{(1)}$} & \multicolumn{6}{|c|}{ Mestiço cultivar } & \multirow[b]{2}{*}{ TDM } & \multirow[b]{2}{*}{ DQI } \\
\hline & APH & SD & NL & LA & APDM & RDM & & \\
\hline$\overline{\mathrm{APH}}$ & 1.00 & 0.09 & 0.06 & 0.29 & 0.24 & 0.18 & 0.24 & -0.01 \\
\hline SD & $0.09^{(2)}$ & 1.00 & 0.14 & 0.17 & 0.09 & -0.05 & 0.05 & 0.52 \\
\hline NL & 0.06 & 0.14 & 1.00 & 0.37 & 0.12 & 0.12 & 0.14 & 0.18 \\
\hline LA & 0.29 & 0.17 & 0.37 & 1.00 & 0.47 & 0.34 & 0.47 & 0.34 \\
\hline APDM & 0.24 & 0.09 & 0.12 & 0.47 & 1.00 & 0.57 & 0.94 & 0.59 \\
\hline RDM & 0.18 & -0.05 & 0.12 & 0.34 & 0.57 & 1.00 & 0.81 & 0.76 \\
\hline TDM & 0.24 & 0.05 & 0.14 & 0.47 & 0.94 & 0.81 & 1.00 & 0.73 \\
\hline QDI & -0.01 & 0.52 & 0.18 & 0.34 & 0.59 & 0.76 & 0.73 & 1.00 \\
\hline \multirow{2}{*}{ Characteristic $^{(1)}$} & \multicolumn{6}{|c|}{ Ozone cultivar } & & \\
\hline & APH & SD & NL & LA & APDM & RDM & TDM & DQI \\
\hline $\mathrm{APH}$ & 1.00 & 0.50 & 0.29 & 0.61 & 0.60 & 0.32 & 0.60 & 0.36 \\
\hline SD & $0.50^{(2)}$ & 1.00 & 0.23 & 0.50 & 0.50 & 0.28 & 0.50 & 0.49 \\
\hline NL & 0.29 & 0.23 & 1.00 & 0.40 & 0.30 & 0.12 & 0.28 & 0.17 \\
\hline LA & 0.61 & 0.50 & 0.40 & 1.00 & 0.80 & 0.42 & 0.79 & 0.55 \\
\hline APDM & 0.60 & 0.50 & 0.30 & 0.80 & 1.00 & 0.44 & 0.95 & 0.61 \\
\hline RDM & 0.32 & 0.28 & 0.12 & 0.42 & 0.44 & 1.00 & 0.68 & 0.96 \\
\hline TDM & 0.60 & 0.50 & 0.28 & 0.79 & 0.95 & 0.68 & 1.00 & 0.81 \\
\hline QDI & 0.36 & 0.49 & 0.17 & 0.55 & 0.61 & 0.96 & 0.81 & 1.00 \\
\hline
\end{tabular}

(1) $\mathrm{APH}=$ aerial part height $(\mathrm{cm}) ; \mathrm{SD}=$ stem diameter $(\mathrm{mm}) ; \mathrm{NL}=$ number of leaves per plant; LA = leaf area $\left(\mathrm{cm}^{2}\right) ; \mathrm{APDM}=$ aerial part dry matter $(\mathrm{g})$; RDM = root dry matter $(\mathrm{g})$; TDM = total dry matter $(\mathrm{g})$; DQI = Dickson quality index.

(2) Very weak correlation between 0.00 to 0.19 ; weak between 0.20 to 0.39 ; moderate between 0.40 to 0.69 ; strong between 0.70 to 0.89 ; and very strong between 0.90 to 1.00 , according to Shimakura \& Júnior (2012). Critical value for statistical significance of the correlations: $r \geq 0.181$, significant at $1 \% ; r \geq 0.138$, significant at $5 \%$. The following hypotheses were used for correlation: $H_{0}: \rho=0$ and $H_{1}: \rho \neq 0$. 
Table 3: Canonical correlations (r) and canonical pairs estimated between destructive characteristics (group I) and non-destructive characteristics (group II) from tomato seedlings (Solanum Iycopersicum), Mestiço and Ozone cultivars

\begin{tabular}{|c|c|c|c|c|}
\hline \multirow{3}{*}{ Characteristic (1) } & \multicolumn{2}{|c|}{ Canonical pairs, 'Mestiço' } & \multicolumn{2}{|c|}{ Canonical pairs, 'Ozone' } \\
\hline & $\mathbf{1}^{\circ}$ & $2^{\circ}$ & $\mathbf{1}^{\circ}$ & $2^{\circ}$ \\
\hline & \multicolumn{2}{|c|}{ Group I } & \multicolumn{2}{|c|}{ Group I } \\
\hline$\overline{\mathrm{APDM}}$ & 0.29 & 0.86 & -0.50 & 1.29 \\
\hline RDM & 1.20 & 0.15 & 1.34 & 3.61 \\
\hline \multirow[t]{2}{*}{ DQI } & -1.60 & 0.08 & -1.70 & -4.18 \\
\hline & \multicolumn{2}{|c|}{ Group II } & \multicolumn{2}{|c|}{ Group II } \\
\hline APH & 0.40 & 0.19 & 0.14 & 0.86 \\
\hline $\mathrm{SD}$ & -0.96 & 0.07 & -0.53 & -0.97 \\
\hline NL & -0.02 & -0.08 & 0.06 & 0.00 \\
\hline LA & 0.04 & 0.94 & -0.74 & 0.36 \\
\hline $\mathrm{r}$ & $0.95 * *(2)$ & $0.49^{* *}$ & $0.82 * *(2)$ & $0.81 * *$ \\
\hline Degrees of freedom & 12 & 6 & 12 & 6 \\
\hline
\end{tabular}

Table 4: Optimum plot size $\left(\mathrm{X}_{0}\right)$, in number of plants, to evaluate the aerial part height, estimated by Hatheway's method, in an experiment disposed by a randomized block design in different scenarios formed by combinations between number of treatments (I) and number of repetitions (R) in tomato seedlings (Solanum Iycopersicum) with error of 10\%, 20\%, 30\% and 40\% around the average

\begin{tabular}{|c|c|c|c|c|c|c|c|c|c|c|c|}
\hline I & $\mathbf{R}$ & $\mathrm{D}=10 \%$ & $\mathrm{D}=\mathbf{2 0 \%}$ & $\mathrm{D}=\mathbf{3 0 \%}$ & $D=40 \%$ & I & $\mathbf{R}$ & $\mathrm{D}=10 \%$ & $\mathrm{D}=\mathbf{2 0 \%}$ & $\mathrm{D}=\mathbf{3 0 \%}$ & $D=40 \%$ \\
\hline 1 & 3 & 7 & 8 & 2 & 1 & 1 & 15 & 2 & 16 & 4 & 2 \\
\hline 2 & 4 & 5 & 10 & 3 & 2 & 1 & 15 & 3 & 15 & 4 & 2 \\
\hline 3 & 4 & 6 & 8 & 2 & 1 & 1 & 15 & 4 & 11 & 3 & 2 \\
\hline 4 & 4 & 7 & 7 & 2 & 1 & 1 & 15 & 5 & 9 & 3 & 1 \\
\hline 5 & 5 & 4 & 13 & 4 & 2 & 1 & 15 & 6 & 8 & 2 & 1 \\
\hline 6 & 5 & 5 & 10 & 3 & 2 & 1 & 15 & 7 & 7 & 2 & 1 \\
\hline 7 & 5 & 6 & 8 & 2 & 1 & 1 & 20 & 2 & 16 & 4 & 2 \\
\hline 8 & 5 & 7 & 7 & 2 & 1 & 1 & 20 & 3 & 15 & 4 & 2 \\
\hline 9 & 6 & 4 & 12 & 3 & 2 & 1 & 20 & 4 & 11 & 3 & 2 \\
\hline 10 & 6 & 5 & 10 & 3 & 2 & 1 & 20 & 5 & 9 & 3 & 1 \\
\hline 11 & 6 & 6 & 8 & 2 & 1 & 1 & 20 & 6 & 8 & 2 & 1 \\
\hline 12 & 6 & 7 & 7 & 2 & 1 & 1 & 20 & 7 & 7 & 2 & 1 \\
\hline 13 & 7 & 3 & 17 & 5 & 2 & 2 & 25 & 2 & 16 & 4 & 2 \\
\hline 14 & 7 & 4 & 12 & 3 & 2 & 1 & 25 & 3 & 15 & 4 & 2 \\
\hline 15 & 7 & 5 & 10 & 3 & 2 & 1 & 25 & 4 & 11 & 3 & 2 \\
\hline 16 & 7 & 6 & 8 & 2 & 1 & 1 & 25 & 5 & 9 & 3 & 1 \\
\hline 17 & 7 & 7 & 7 & 2 & 1 & 1 & 25 & 6 & 8 & 2 & 1 \\
\hline 18 & 8 & 3 & 16 & 4 & 2 & 1 & 25 & 7 & 7 & 2 & 1 \\
\hline 19 & 8 & 4 & 12 & 3 & 2 & 1 & 30 & 2 & 15 & 4 & 2 \\
\hline 20 & 8 & 5 & 9 & 3 & 1 & 1 & 30 & 3 & 15 & 4 & 2 \\
\hline 21 & 8 & 6 & 8 & 2 & 1 & 1 & 30 & 4 & 11 & 3 & 2 \\
\hline 22 & 8 & 7 & 7 & 2 & 1 & 1 & 30 & 5 & 9 & 3 & 1 \\
\hline 23 & 9 & 3 & 16 & 4 & 2 & 1 & 30 & 6 & 8 & 2 & 1 \\
\hline 24 & 9 & 4 & 12 & 3 & 2 & 1 & 30 & 7 & 6 & 2 & 1 \\
\hline 25 & 9 & 5 & 9 & 3 & 1 & 1 & 35 & 2 & 15 & 4 & 2 \\
\hline 26 & 9 & 6 & 8 & 2 & 1 & 1 & 35 & 3 & 15 & 4 & 2 \\
\hline 27 & 9 & 7 & 7 & 2 & 1 & 1 & 35 & 4 & 11 & 3 & 2 \\
\hline 28 & 10 & 2 & 18 & 5 & 2 & 2 & 35 & 5 & 9 & 3 & 1 \\
\hline 29 & 10 & 3 & 16 & 4 & 2 & 1 & 35 & 6 & 7 & 2 & 1 \\
\hline 30 & 10 & 4 & 12 & 3 & 2 & 1 & 35 & 7 & 6 & 2 & 1 \\
\hline 31 & 10 & 5 & 9 & 3 & 1 & 1 & 40 & 2 & 15 & 4 & 2 \\
\hline 32 & 10 & 6 & 8 & 2 & 1 & 1 & 40 & 3 & 15 & 4 & 2 \\
\hline 33 & 10 & 7 & 7 & 2 & 1 & 1 & 40 & 4 & 11 & 3 & 2 \\
\hline
\end{tabular}


$(\mathrm{I}-1) *(\mathrm{R}-1)$ for randomized blocks experiment. In this equation, the values of the coefficient of heterogeneity (b) and the coefficient of variation (CV) for each characteristic were obtained by bootstrap simulation, with 2000 resamples, according to Celanti et al. (2016a), being, in this case, $b=1.0$. For each characteristic, $X_{0}$ was determined only for one tomato cultivar, which presented the greatest data variability, measured by coefficient of variation, according to Cargnelutti Filho et al. (2015).

As it is a discrete random variable, the optimum plot size will be presented by an integer, adopting the correct rounding criterion (Pimentel-Gomes, 1984). The analyzes of descriptive statistics, Pearson correlation and canonical were performed using the Genes program (Cruz, 2016) and the determination of the optimum plot size through the $\mathrm{R}$ program (R Core Team, 2017).

\section{RESULTS AND DISCUSSION}

The table 1 shows the data of the descriptive statistics for the eight characteristics evaluated. The differences between the cultivars were evident, the only characteristic that the average did not differ statistically between one cultivar and another was the stem diameter. In this work, a greater variation is noticed for the variables root dry matter and Dickson quality index, showing a high dispersion among the data, according to Pimentel-Gomes (1985) classification. This variation in the root weight may have been influenced by uneven conditions (temperature, water, etc.) of the seedlings, which can affect germination, emergence and rooting being irregular (Melo et al., 2007).

The phenotypic correlations between the eight characteristics, in the two tomato cultivars, evaluated by Pearson's correlation, are shown in Table 2. The Mestiço

Table 5: Optimum plot size $\left(X_{0}\right)$, in number of plants, to evaluate the stem diameter, estimated by Hatheway's method, in an experiment disposed in a randomized block design in different scenarios formed by combinations between number of treatments (I) and number of repetitions (R) in tomato seedlings (Solanum lycopersicum), with error of 10\%, 20\%, 30\% and 40\% around the average

\begin{tabular}{|c|c|c|c|c|c|c|c|c|c|c|c|}
\hline I & $\mathbf{R}$ & $D=10 \%$ & $\mathrm{D}=\mathbf{2 0} \%$ & $\mathrm{D}=\mathbf{3 0} \%$ & $\mathrm{D}=\mathbf{4 0} \%$ & I & $\mathbf{R}$ & $\mathrm{D}=10 \%$ & $D=20 \%$ & $\mathrm{D}=\mathbf{3 0} \%$ & $D=40 \%$ \\
\hline 3 & 7 & 17 & 5 & 2 & 2 & 15 & 2 & 38 & 10 & 5 & 3 \\
\hline 4 & 5 & 23 & 6 & 3 & 2 & 15 & 3 & 35 & 9 & 4 & 3 \\
\hline 4 & 6 & 19 & 5 & 3 & 2 & 15 & 4 & 26 & 7 & 3 & 2 \\
\hline 4 & 7 & 16 & 4 & 2 & 1 & 15 & 5 & 20 & 5 & 3 & 2 \\
\hline 5 & 4 & 29 & 8 & 4 & 2 & 15 & 6 & 17 & 5 & 2 & 2 \\
\hline 5 & 5 & 22 & 6 & 3 & 2 & 15 & 7 & 15 & 4 & 2 & 1 \\
\hline 5 & 6 & 18 & 5 & 2 & 2 & 20 & 2 & 36 & 9 & 4 & 3 \\
\hline 5 & 7 & 15 & 4 & 2 & 1 & 20 & 3 & 34 & 9 & 4 & 3 \\
\hline 6 & 4 & 28 & 7 & 4 & 2 & 20 & 4 & 25 & 7 & 3 & 2 \\
\hline 6 & 5 & 22 & 6 & 3 & 2 & 20 & 5 & 20 & 5 & 3 & 2 \\
\hline 6 & 6 & 18 & 5 & 2 & 2 & 20 & 6 & 17 & 5 & 2 & 2 \\
\hline 6 & 7 & 15 & 4 & 2 & 1 & 20 & 7 & 14 & 4 & 2 & 1 \\
\hline 7 & 3 & 39 & 10 & 5 & 3 & 25 & 2 & 35 & 9 & 4 & 3 \\
\hline 7 & 4 & 27 & 7 & 3 & 2 & 25 & 3 & 34 & 9 & 4 & 3 \\
\hline 7 & 5 & 21 & 6 & 3 & 2 & 25 & 4 & 25 & 7 & 3 & 2 \\
\hline 7 & 6 & 18 & 5 & 2 & 2 & 25 & 5 & 20 & 5 & 3 & 2 \\
\hline 7 & 7 & 15 & 4 & 2 & 1 & 25 & 6 & 17 & 5 & 2 & 2 \\
\hline 8 & 3 & 38 & 10 & 5 & 3 & 25 & 7 & 14 & 4 & 2 & 1 \\
\hline 8 & 4 & 27 & 7 & 3 & 2 & 30 & 2 & 35 & 9 & 4 & 3 \\
\hline 8 & 5 & 21 & 6 & 3 & 2 & 30 & 3 & 34 & 9 & 4 & 3 \\
\hline 8 & 6 & 17 & 5 & 2 & 2 & 30 & 4 & 25 & 7 & 3 & 2 \\
\hline 8 & 7 & 15 & 4 & 2 & 1 & 30 & 5 & 20 & 5 & 3 & 2 \\
\hline 9 & 3 & 37 & 10 & 5 & 3 & 30 & 6 & 17 & 5 & 2 & 2 \\
\hline 9 & 4 & 27 & 7 & 3 & 2 & 30 & 7 & 14 & 4 & 2 & 1 \\
\hline 9 & 5 & 21 & 6 & 3 & 2 & 35 & 2 & 35 & 9 & 4 & 3 \\
\hline 9 & 6 & 17 & 5 & 2 & 2 & 35 & 3 & 34 & 9 & 4 & 3 \\
\hline 9 & 7 & 15 & 4 & 2 & 1 & 35 & 4 & 25 & 7 & 3 & 2 \\
\hline 10 & 2 & 41 & 11 & 5 & 3 & 35 & 5 & 20 & 5 & 3 & 2 \\
\hline 10 & 3 & 36 & 9 & 4 & 3 & 35 & 6 & 17 & 5 & 2 & 2 \\
\hline 10 & 4 & 26 & 7 & 3 & 2 & 35 & 7 & 14 & 4 & 2 & 1 \\
\hline 10 & 5 & 21 & 6 & 3 & 2 & 40 & 2 & 34 & 9 & 4 & 3 \\
\hline 10 & 6 & 17 & 5 & 2 & 2 & 40 & 3 & 33 & 9 & 4 & 3 \\
\hline 10 & 7 & 15 & 4 & 2 & 1 & 40 & 4 & 25 & 7 & 3 & 2 \\
\hline
\end{tabular}

Rev. Ceres, Viçosa, v. 68, n.2, p. 126-134, mar/apr, 2021 
cultivar presented most of the correlations $\leq$ at 0.40 , demonstrating a low linear association and, consequently, low magnitude, in contrast with the Ozone cultivar, which presented, in general, the majority of correlations $\geq$ at 0.40 , with correlations ranging from moderate to very strong, demonstrating a significant linear association and of good magnitude (Hair et al., 2005). Divergence between such cultivars can be explained by the difference between their characteristics, the 'Mestiço' presented a larger size than 'Ozone', in addition to the more varied number of leaves and higher dry matter weight, the Ozone cultivar showed, in general, greater uniformity, mainly regarding the number of leaves and dry matter among a plant and another, i.e., in 'Mestiço', 71\% of the correlations were significant at 5\% by the $t$ test and, in 'Ozone', $96 \%$ of the correlations were significant at $5 \%$ by the t test. However, considering that the size of each sample is considered large, $n=200$ seedlings, a correlation with $r$ value $\geq 0.138$ is considered significant and, according to Shimakura \& Júnior (2012) classification, a correlation up to 0,19 is considered very weak.

Considering only the correlations considered moderate or higher $(r \geq 0.40)$, these are found in $32 \%$ of the 'Mestiço' correlations and $68 \%$ of the 'Ozone' correlations. For non-destructive characteristics, the correlations between these characteristics were more expressive in 'Ozone'. The most expressive correlations, in both cultivars, were between the dry matter characteristics and these with Dickson quality index, showing that, if it is necessary to determine the optimum plot size for these characteristics, which are destructive, there is no need to use all of them.

Table 6: Optimum plot size $\left(\mathrm{X}_{0}\right)$, in number of plants, for assessing the number of leaves per plant, estimated by Hatheway's method in an experiment disposed in a randomized block design in different scenarios formed by combinations between number of treatments (I) and number of repetitions (R) in tomato seedlings (Solanum Iycopersicum) with error of 10\%, 20\%, 30\% and 40\% around the average

\begin{tabular}{|c|c|c|c|c|c|c|c|c|c|c|c|}
\hline I & $\mathbf{R}$ & $D=10 \%$ & $D=20 \%$ & $\mathrm{D}=\mathbf{3 0} \%$ & $D=40 \%$ & I & $\mathbf{R}$ & $\mathrm{D}=10 \%$ & $\mathrm{D}=\mathbf{2 0} \%$ & $\mathrm{D}=\mathbf{3 0} \%$ & $D=40 \%$ \\
\hline 1 & 3 & 7 & 8 & 2 & 1 & 1 & 15 & 2 & 16 & 4 & 2 \\
\hline 2 & 4 & 5 & 10 & 3 & 2 & 1 & 15 & 3 & 15 & 4 & 2 \\
\hline 3 & 4 & 6 & 8 & 2 & 1 & 1 & 15 & 4 & 11 & 3 & 2 \\
\hline 4 & 4 & 7 & 7 & 2 & 1 & 1 & 15 & 5 & 9 & 3 & 1 \\
\hline 5 & 5 & 4 & 13 & 4 & 2 & 1 & 15 & 6 & 8 & 2 & 1 \\
\hline 6 & 5 & 5 & 10 & 3 & 2 & 1 & 15 & 7 & 7 & 2 & 1 \\
\hline 7 & 5 & 6 & 8 & 2 & 1 & 1 & 20 & 2 & 16 & 4 & 2 \\
\hline 8 & 5 & 7 & 7 & 2 & 1 & 1 & 20 & 3 & 15 & 4 & 2 \\
\hline 9 & 6 & 4 & 12 & 3 & 2 & 1 & 20 & 4 & 11 & 3 & 2 \\
\hline 10 & 6 & 5 & 10 & 3 & 2 & 1 & 20 & 5 & 9 & 3 & 1 \\
\hline 11 & 6 & 6 & 8 & 2 & 1 & 1 & 20 & 6 & 8 & 2 & 1 \\
\hline 12 & 6 & 7 & 7 & 2 & 1 & 1 & 20 & 7 & 7 & 2 & 1 \\
\hline 13 & 7 & 3 & 17 & 5 & 2 & 2 & 25 & 2 & 16 & 4 & 2 \\
\hline 14 & 7 & 4 & 12 & 3 & 2 & 1 & 25 & 3 & 15 & 4 & 2 \\
\hline 15 & 7 & 5 & 10 & 3 & 2 & 1 & 25 & 4 & 11 & 3 & 2 \\
\hline 16 & 7 & 6 & 8 & 2 & 1 & 1 & 25 & 5 & 9 & 3 & 1 \\
\hline 17 & 7 & 7 & 7 & 2 & 1 & 1 & 25 & 6 & 8 & 2 & 1 \\
\hline 18 & 8 & 3 & 16 & 4 & 2 & 1 & 25 & 7 & 7 & 2 & 1 \\
\hline 19 & 8 & 4 & 12 & 3 & 2 & 1 & 30 & 2 & 15 & 4 & 2 \\
\hline 20 & 8 & 5 & 9 & 3 & 1 & 1 & 30 & 3 & 15 & 4 & 2 \\
\hline 21 & 8 & 6 & 8 & 2 & 1 & 1 & 30 & 4 & 11 & 3 & 2 \\
\hline 22 & 8 & 7 & 7 & 2 & 1 & 1 & 30 & 5 & 9 & 3 & 1 \\
\hline 23 & 9 & 3 & 16 & 4 & 2 & 1 & 30 & 6 & 8 & 2 & 1 \\
\hline 24 & 9 & 4 & 12 & 3 & 2 & 1 & 30 & 7 & 6 & 2 & 1 \\
\hline 25 & 9 & 5 & 9 & 3 & 1 & 1 & 35 & 2 & 15 & 4 & 2 \\
\hline 26 & 9 & 6 & 8 & 2 & 1 & 1 & 35 & 3 & 15 & 4 & 2 \\
\hline 27 & 9 & 7 & 7 & 2 & 1 & 1 & 35 & 4 & 11 & 3 & 2 \\
\hline 28 & 10 & 2 & 18 & 5 & 2 & 2 & 35 & 5 & 9 & 3 & 1 \\
\hline 29 & 10 & 3 & 16 & 4 & 2 & 1 & 35 & 6 & 7 & 2 & 1 \\
\hline 30 & 10 & 4 & 12 & 3 & 2 & 1 & 35 & 7 & 6 & 2 & 1 \\
\hline 31 & 10 & 5 & 9 & 3 & 1 & 1 & 40 & 2 & 15 & 4 & 2 \\
\hline 32 & 10 & 6 & 8 & 2 & 1 & 1 & 40 & 3 & 15 & 4 & 2 \\
\hline 33 & 10 & 7 & 7 & 2 & 1 & 1 & 40 & 4 & 11 & 3 & 2 \\
\hline
\end{tabular}


Pearson's correlation coefficients, although important, only make the linear relationship between two characteristics at a time. In order to relate the set of destructive characteristics with that of non-destructive ones, the analysis of canonical correlations was carried out, whose results are expressed in Table 3. In these canonical correlations, the total dry matter characteristic does not appear because it showed multicollinearity with other destructive characteristics and was discarded from the analyzes. Canonical correlations were significant by the chi-square test. This demonstrates that the two groups of characters are related in a dependent way (Cruz \& Regazzi, 2001). Consequently, the first two canonical pairs are of interest to the study. By studying the coefficients of the first canonical pair, in 'Mestiço', it is evident that the larger the diameter of the seedling collection, the greater the Dickson quality index. This same relationship is also valid when studying the second canonical pair in 'Ozone'.

Thus, in this work, it was found that there is a possibility to determine the optimum plot size only by non-destructive characteristics.

Considering that two cultivars were evaluated and that there is different phenotypic variability between the two cultivars, detected by dispersion measurements (Table 1) and by linear correlations (Table 2), it was decided to use, in determining the optimum plot size, only the highest coefficient of variation values, understanding that they express the greatest variability of the data, as suggested by Cargnelutti Filho et al. (2017). Thus, for the determination of the optimum plot size for the seedling aerial part height (Table 4) and stem diameter (Table 5), the data obtained in 'Mestiço' seedlings were used and, to determine the optimum plot size for number of leaves

Table 7: Optimum plot size $\left(\mathrm{X}_{0}\right)$, in number of plants, for leaf area assessment, estimated by Hatheway's method in an experiment disposed in a randomized block design in different scenarios formed by combinations between number of treatments (I) and number of repetitions (R) in tomato seedlings (Solanum Iycopersicum) with error of 10\%, 20\%, 30\% and 40\% around the average

\begin{tabular}{|c|c|c|c|c|c|c|c|c|c|c|c|}
\hline I & $\mathbf{R}$ & $D=10 \%$ & $\mathrm{D}=\mathbf{2 0} \%$ & $\mathrm{D}=\mathbf{3 0} \%$ & $D=40 \%$ & I & $\mathbf{R}$ & $\mathrm{D}=10 \%$ & $D=20 \%$ & $\mathrm{D}=\mathbf{3 0} \%$ & $D=40 \%$ \\
\hline 1 & 3 & 7 & 13 & 4 & 2 & 1 & 15 & 2 & 30 & 8 & 4 \\
\hline 2 & 4 & 5 & 18 & 5 & 2 & 2 & 15 & 3 & 27 & 7 & 3 \\
\hline 3 & 4 & 6 & 15 & 4 & 2 & 1 & 15 & 4 & 20 & 5 & 3 \\
\hline 4 & 4 & 7 & 13 & 4 & 2 & 1 & 15 & 5 & 16 & 4 & 2 \\
\hline 5 & 5 & 4 & 23 & 6 & 3 & 2 & 15 & 6 & 13 & 4 & 2 \\
\hline 6 & 5 & 5 & 18 & 5 & 2 & 2 & 15 & 7 & 12 & 3 & 2 \\
\hline 7 & 5 & 6 & 14 & 4 & 2 & 1 & 20 & 2 & 28 & 7 & 4 \\
\hline 8 & 5 & 7 & 12 & 3 & 2 & 1 & 20 & 3 & 27 & 7 & 3 \\
\hline 9 & 6 & 4 & 22 & 6 & 3 & 2 & 20 & 4 & 20 & 5 & 3 \\
\hline 10 & 6 & 5 & 17 & 5 & 2 & 2 & 20 & 5 & 16 & 4 & 2 \\
\hline 11 & 6 & 6 & 14 & 4 & 2 & 1 & 20 & 6 & 13 & 4 & 2 \\
\hline 12 & 6 & 7 & 12 & 3 & 2 & 1 & 20 & 7 & 11 & 3 & 2 \\
\hline 13 & 7 & 3 & 30 & 8 & 4 & 2 & 25 & 2 & 28 & 7 & 4 \\
\hline 14 & 7 & 4 & 22 & 6 & 3 & 2 & 25 & 3 & 27 & 7 & 3 \\
\hline 15 & 7 & 5 & 17 & 5 & 2 & 2 & 25 & 4 & 20 & 5 & 3 \\
\hline 16 & 7 & 6 & 14 & 4 & 2 & 1 & 25 & 5 & 16 & 4 & 2 \\
\hline 17 & 7 & 7 & 12 & 3 & 2 & 1 & 25 & 6 & 13 & 4 & 2 \\
\hline 18 & 8 & 3 & 30 & 8 & 4 & 2 & 25 & 7 & 11 & 3 & 2 \\
\hline 19 & 8 & 4 & 21 & 6 & 3 & 2 & 30 & 2 & 27 & 7 & 3 \\
\hline 20 & 8 & 5 & 17 & 5 & 2 & 2 & 30 & 3 & 26 & 7 & 3 \\
\hline 21 & 8 & 6 & 14 & 4 & 2 & 1 & 30 & 4 & 20 & 5 & 3 \\
\hline 22 & 8 & 7 & 12 & 3 & 2 & 1 & 30 & 5 & 16 & 4 & 2 \\
\hline 23 & 9 & 3 & 29 & 8 & 4 & 2 & 30 & 6 & 13 & 4 & 2 \\
\hline 24 & 9 & 4 & 21 & 6 & 3 & 2 & 30 & 7 & 11 & 3 & 2 \\
\hline 25 & 9 & 5 & 17 & 5 & 2 & 2 & 35 & 2 & 27 & 7 & 3 \\
\hline 26 & 9 & 6 & 14 & 4 & 2 & 1 & 35 & 3 & 26 & 7 & 3 \\
\hline 27 & 9 & 7 & 12 & 3 & 2 & 1 & 35 & 4 & 20 & 5 & 3 \\
\hline 28 & 10 & 2 & 32 & 8 & 4 & 2 & 35 & 5 & 16 & 4 & 2 \\
\hline 29 & 10 & 3 & 29 & 8 & 4 & 2 & 35 & 6 & 13 & 4 & 2 \\
\hline 30 & 10 & 4 & 21 & 6 & 3 & 2 & 35 & 7 & 11 & 3 & 2 \\
\hline 31 & 10 & 5 & 16 & 4 & 2 & 1 & 40 & 2 & 27 & 7 & 3 \\
\hline 32 & 10 & 6 & 14 & 4 & 2 & 1 & 40 & 3 & 26 & 7 & 3 \\
\hline 33 & 10 & 7 & 12 & 3 & 2 & 1 & 40 & 4 & 20 & 5 & 3 \\
\hline
\end{tabular}

Rev. Ceres, Viçosa, v. 68, n.2, p. 126-134, mar/apr, 2021 
(Table 6) and leaf area per seedling (Table 7), data from the cultivar Ozone was used.

Observing the results from Table 4 to 7 , it can be seen that the plot size is different among the evaluated characteristics, as also observed by Celanti et al. (2016b), with papaya seedlings. Considering the same number of treatments, repetitions and the same experimental precision, the largest required plot size was for the characteristic stem diameter. Thus, if the experimenter wants to evaluate the non-destructive characteristics in his experiment, just consult table 4. As an example, if he wants to establish an experiment with tomato seedlings with 10 treatments and 4 repetitions, with an accuracy of $20 \%$ around the average, he will have to evaluate seven seedlings per plot.

\section{CONCLUSIONS}

The characteristics showed variability, so the optimum plot size varies according to the character evaluated. As the Dickson quality index had a relationship with the stem diameter, considering that it is a destructive variable, it can be dispensed with the determination of the optimum plot size, being used instead the stem diameter.

The stem diameter can be used as a basis for all nondestructives characteristics, without the need to destroy the seedlings.

\section{ACKNOWLEDGEMENTS, FINANCIAL SUPPORT AND FULL DISCLOSURE}

To Coordination for the Improvement of Higher Education Personnel (CAPES) for the support to this research.

The authors inform that there is no conflict of interests in carrying out the research and publishing this manuscript.

\section{REFERENCES}

Bernardes JM, Reis JMR \& Rodrigues JF (2011) Effect of the application of humic substance on tomato seedlings. Global Science and Technology, 4:92-99.

Brito MCM, Humada-González GM, Morais AR \& Moreira JM (2014) Avaliação do desempenho do algoritmo de reamostragem bootstrap na verificação da estimação do tamanho ótimo da parcela. Revista da Estatística UFOP, 3:255-259.

Cargnelutti Filho A, Toebe M, Burin C, Alves BM, Facco G \& Stefanello RB (2015) Tamanho de parcela para avaliar caracteres de tremoço branco em épocas de avaliação. Ciência Rural, 45:206-214.

Cargnelutti Filho A, Alves BM, Follmann DN, Bem CM, Schabarum DE, Stefanelo LS, Wartha CA, Kleinpaul JA, Chaves GG, Uliana DB \& Pezzini RV (2017) Plot size and number of repetitions in vetch. Bragantia, 76:178-188

Celanti HF, Schmildt ER, Schmildt O, Alexandre RS \& Cattaneo LF (2016a) Optimal plot size in the evaluation of papaya scions: proposal and comparison of methods. Revista Ceres, 63:469476
Celanti HF, Schmildt O, Alexandre RS, Cattaneo LF \& Schmildt ER (2016b) Plot size in the evaluation of papaya seedlings 'Baixinho de Santa Amália' in tubes. Revista Brasileira de Fruticultura, 38:1-15.

Cruz CD \& Regazzi AJ (2001) Modelos biométricos aplicados ao melhoramento genético. $2^{\text {nd }}$ ed. Viçosa, Editora UFV. 390p.

Cruz CD (2016) Genes Software-extended and integrated with the R, Matlab and Selegen. Acta Scientiarum. Agronomy, 38:547552 .

Dickson A, Leaf A \& Hosner J (1960) Quality appraisal of white spruce and white pine seedling stock in nurseries. Forestry Chronicle, 36:10-13.

Hair JF, Anderson RE, Tatham RL \& Black WC (2005) Análise multivariada de dados. $5^{\text {th }}$ ed. Porto Alegre, Bookman. 593p.

Hatheway WH (1961) Convenient plot size. Agronomy Journal, 53:279-280

Leonardo FAP, Pereira WE, Silva SM, Araújo RC \& Mendonça RMN (2014) Tamanho ótimo da parcela experimental de abacaxizeiro 'Vitória'. Revista Brasileira de Fruticultura, 3:909. 916.

Melo PCT (2007) Produção de sementes de tomate para mesa. In: Curso sobre tecnologia de produção de sementes de hortaliças, Brasília. Embrapa Hortaliças. CD-ROM.

Meier VD \& Lessman KJ (1971) Estimation of Optimum Field Plot Shape and Size For Testing Yield in Crambe abysinica Hochst. Crop Science, 11:648-650.

Nadai FB, Menezes JBC, Catão HCRM, Advícula T \& Costa CA (2015) Production of tomato seedlings according to different ways of propagation and substrates. Revista Agro@mbiente Online, 9:261-267.

Paranaíba PF, Ferreira DF \& Morais AR de (2009) Tamanho ótimo de parcelas experimentais: proposição de métodos de estimação. Revista Brasileira de Biometria, 27:255-268.

Pimentel-Gomes F (1984) O problema do tamanho das parcelas em experimentos com plantas arbóreas. Pesquisa Agropecuária Brasileira, 19:1507-1512.

Pimentel-Gomes F (1985) Curso de Estatística Experimental. São Paulo, Nobel. 467p.

R Core Team (2017) R: a language and environment for statistical computing. Vienna, R Foundation for Statistical Computing. Available at: https://www.R-project.org/ Accessed on: February $22^{\text {th }}, 2021$.

Santos D, Haesbaert FM, Lúcio AD, Storck L \& Cargnelutti Filho A (2012) Tamanho ótimo de parcela para a cultura do feijãovagem. Revista Ciência Agronômica, 43:119-128.

Schindelin J, Rueden CT, Hiner M \& Eliceiri KW (2015) The ImageJ Ecosystem: An Open Platform for Biomedical Image Analysis. Molecular Reproduction and Development, 82:518529.

Shimakura S \& Júnior PJR (2012) Estatística Descritiva: Interpretação do coeficiente de correlação. Available at: http:// leg.ufpr.br/ paulojus/CE003/ce003/node8.html. Accessed on: August $8^{\text {th }}, 2018$.

Sirtoli LF, Cerqueira RC, Rodrigues JD, Goto R \& Braga CL (2011) Enxertia no desenvolvimento e qualidade de frutos de tomateiro sob diferentes porta-enxertos em cultivo protegido. Scientia Agraria Paranaensis, 10:15-22.

Smith HF (1938) An empirical law describing heterogeneity in the yields of agricultural crops. The Journal of Agricultural Science, $28: 1-23$.

Rev. Ceres, Viçosa, v. 68, n.2, p. 126-134, mar/apr, 2021 
Soares LAA, Lima GS, Brito MEB, Araújo TT, Sá FVS \& Silva ECB da (2013) Morfofisiologia e qualidade pós-colheita do tomateiro sob estresse hídrico nas fases fenológicas. Revista Verde de Agroecologia e Desenvolvimento Sustentável, 8:239-246.

Storck L, Garcia DC, Lopes SJ \& Estefanel V (2011) Experimentação vegetal. $3^{\text {th }}$ ed. Santa Maria, UFSM. 198 p.
Storck L, Lúcio AD, Krause W, Araújo DV \& Silva CA (2014) Dimensionamento do número de plantas por parcela e do número de parcelas por genótipo de maracujá-amarelo. Acta Scientiarum Agronomy, 36:73-78. 